\title{
Pesan Politik Calon Presiden dan Wakil Presiden di Media Sosial Instagram pada Pemilihan Umum Tahun 2019
}

\author{
Rismawati, Suryanef \\ Prodi Pendidikan Pancasila dan Kewarganegaraan \\ FIS Universitas Negeri Padang \\ E-mail: suryanef@fis.unp.ac.id
}

\section{ABSTRAK}

Penelitian ini bertujuan untuk mengungkapkan pesan politik calon presiden dan wakil presiden pada pemilihan umum tahun 2019 melalui media sosial instagram. Penelitian ini merupakan penelitian kualitatif dengan teknik penelitian analisis isi. Data yang digunakan dalam penelitian ini adalah hasil postingan pada instagram yang memuat pesan politik pasangan calon Presiden dan Wakil Presiden. Penelitian ini dilakukan dalam rentang waktu November 2018 - April 2019 yang dimulai dari masa pencalonan hingga masa kampanye berlangsung. Hasil penelitian menunjukkan bahwa kedua pasang calon Presiden dan Wakil Presiden menyampaikan pesan politik di bidang sosial, ekonomi, politik dan budaya kepada masyarakat. Pesan tersebut belum mencerminkan kenyataan yang ada di masyarakat karena masih bersifat umum dan belum spesifik mengatasi persepsi publik tentang ketimpangan social.

Kata Kunci: komunikasi politik, pesan politik, media sosial, instagram

\section{ABSTRACT}

This study aims to reveal the political messages of presidential and vice presidential candidates in the 2019 general election in Indonesia through social media Instagram. This research is a qualitative research with content analysis research techniques. The data used in this study are the results of postings on Instagram that contain political messages for the presidential and vice presidential candidates. This research was conducted in the period November 2018 - April 2019 starting from the nomination period until the campaign period. The results showed that the two pairs of candidates for President and Vice President conveyed political messages in the social, economic, political and cultural fields to the public. The message does not reflect the reality that exists in society because it is still general and has not specifically addressed public perceptions of social inequality.

Keywords: political communication, political message, social media, instagram 


\section{PENDAHULUAN}

Komunikasi politik merupakan sebuah proses ketika informasi politik yang relevan ditentukan dari suatu bagian system politik ke bagian lainnya dan diantara system sosial dengan system politik (Althoff, 1989). Komunikasi politik merupakan salah satu fungsi partai politik dalam menyalurkan beragam pendapat dan aspirasi masyarakat serta mengaturnya sedemikian rupa untuk diperjuangkan menjadi kebijakan politik (Budiarjo, 2008).

Pemilihan Presiden dan wakil Presiden merupakan ciri negara demokrasi yang memberikan kesempatan bagi masyarakat Indonesia untuk memilih pemimpin yang sesuai dengan hati nurani. Komisi Pemilihan Umum Republik Indonesia (KPU RI) memberikan ruang kepada kandidat calon untuk mensosialisasikan dirinya melalui beberapa alat peraga kampanye seperti: baliho, spanduk, pamflet hingga media sosial.

Penggunaaan media sosial dalam pemilihan Presiden dan wakil Presiden merupakan hal yang wajar pada saat ini. Keberadaan media sosial sebagai instrumen pembentuk komunikasi politik dapat dimaksimalkan oleh pasangan calon presiden dan wakil presiden. Hal ini disebabkan karena media sosial dinilai unggul dalam memberikan kecepatan informasi (Damayanti dan Purworini, 2018). Namun, di sisi lainnya, media sosial dapat membuat penggunanya semakin apatis dalam pemilihan presiden tahun 2019.

Pada kenyataannya, pesan politik yang disampaikan melalui media sosial oleh calon Presiden dan wakil Presiden belum menyentuh isu- isu dalam masyarakat, misalnya pengangguran. Salah satu calon Presiden mengatakan akan ada pertumbuhan ekonomi sebesar 7\% namun hingga saat ini masih banyak masyarakat yang belum mendapatkan pekerjaan.

Kehadiran dunia virtual membuka kesempatan tiap pihak yang terlibat untuk mengeksistensikan dirinya dengan lebih luas (Watie, 2016). Melalui status, komentar, notes, dan berbagai fasilitas dalam sosial media tersebut banyak orang berusaha menunjukkan keberadaannya dengan terus memperbaharui segala perkembangan yang ada. Suatu perkembangan yang jika di dunia nyata tak mungkin disampaikan.

Komunikasi politik merupakan diskusi publik mengenai penjatahan mengenai sumber daya publik yakni mengenai pembagian pendapatan atau penghasilan yang diterima oleh public. Kewenangan resmi yakni siapa yang memberi kekuasaan untuk membuat keputusan-keputusan hukum, membuat peraturanperaturan, dan melaksanakan peraturan-peraturan, serta sanksisanksi resmi yakni apa yang negara berikan sebagai ganjaran atau mungkin hukuman (Pawito, 2009).

Sementara itu, komunikator politik adalah orang yang dapat memberi informasi tentang hal-hal yang mengandung makna politik, misalnya: presiden, menteri, anggota DPR, politisi, dan kelompokkelompok penekan dalam masyarakat yang bisa mempengaruhi jalannya pemerintahan. Komunikator ini menyampaikan pesan politik yang berisi pernyataan baik secara tertulis 
maupun tidak tertulis, verbal maupun nonverbal, tersembunyi maupun terang-terangan, disadari maupun tidak disadari yang isinya mengandung politik. Misalnya pidato politik, pernyataan politik, buku, brosur dan berita surat kabar mengenai politik.

Pengaruh pesan terhadap masyarakat sangat dipengaruhi oleh komunikator, bentuk layout, jenis huruf, warna tulisan dan lain-lainnya (Mulyana, 2010). Pesan yang sama dapat menimbulkan pengaruh berbeda bila disampaikan oleh orang yang berbeda. Begitu juga saluran dan media komunikasi yang dipakai mempengaruhi penyampaian pesan.

Pesan politik ialah makna dan aturan kata dalam pembicaraan politik yang dapat menghasilkan berbagai makna, struktur, dan akibat. Namun secara bahasa pesan politik dapat berarti suatu sistem yang tersusun dari kombinasi lambanglambang yang signifikan. Pesan politik juga bisa disampaikan melalui gambar-gambar seperti karikatur yang bersifat menyindir atau pesanpesan politik berupa kritikan.

Media politik merupakan sarana yang digunakan oleh para komunikator dalam menyampaikan pesan-pesan politiknya. Efek komunikasi politik yang diharapkan adalah terciptanya pemahaman terhadap sistem pemerintahan dan partai-partai politik. Masyarakat diharapkan aktif berpartisipasi dalam politik dengan memberikan suara dalam Pemilihan Umum.

Media sosial merupakan bagian dari media baru yang memiliki muatan interaktif yang tinggi. Sosial media dilihat sebagai demokratisasi isi serta perubahan peran publik dalam membaca dan menyebarkan informasi (Solis \& Breakendridge, 2009). Keberadaan media sosial merupakan bentuk yang tidak jauh berbeda dengan keberadaan dan cara kerja komputer. Di dalamnya terdapat aspek: pengenalan, komunikasi, dan kerja sama yang membentuk sebuah sistem antara individu dan masyarakat (Nasrullah, 2015).

Pada saat sekarang ini, aktivitas yang dilakukan melalui daring sangat intensif dengan berbagai tujuan dan motif. Isu-isu yang terkait dengan penggunaan media sosial yang relatif menyita perhatian yaitu budaya berbagi (share). Fenomena budaya berbagi ini makin meningkat saat Pilpres 2019. Beberapa figur ternama pendukung capres tertentu dengan atau tanpa sengaja memelintir berita, mengomentari lalu menjatuhan lawan politiknya. Hal ini juga dilakukan oleh media partisipan.

Pola-pola pemberitaan hoax pun relatif selalu sama, yaitu dengan membuat judul bombastis untuk menarik minat pembaca. Terkadang antara judul dan isi berita tidak sinkron. Namun, banyak pengguna media sosial di negeri ini yang malas membaca. Mereka cenderung mudah terprovokasi oleh judul yang tampak menarik dan langsung membagikan tautan laman tertentu tanpa menelaah lebih dulu.

Realita masyarakat Indonesia, bahkan dunia saat ini tampaknya menarik untuk dilihat dari perspektif kognisi sosial. Menurut Baron \& Byrne (2003) kognisi sosial merupakan cara kerja pikiran manusia untuk memahami lingkungan sekitar agar manusia dapat berfungsi di dalamnya secara adaptif. Cara kerja pikiran ini 
meliputi aktivitas meng-interpretasi, menganalisis, mengingat, dan menggunakan informasi tentang dunia sosial.

Skema yang terjadi menimbulkan efek yang kuat pada tiga proses dasar: perhatian (attention), pengodean (encoding), dan mengingat kembali (retrieval). Dalam hubungannya dengan perhatian, skema berperan sebagai penyaring informasi yang konsisten dengan skema lebih diperhatikan untuk diolah dalam kesadaran manusia. Sedang-kan informasi yang tidak cocok sering kali diabaikan.

Berdasarkan latar belakang tersebut, maka artikel ini bertujuan untuk mengungkapkan bagaimana pesan politik calon presiden dan wakil presiden pada pemilihan umum tahun 2019 melalui media sosial instagram. Instagram merupakan media sosial yang menarik untuk diteliti karena banyak digunakan oleh generasi milenial dan berbasiskan gambar.

\section{METODE PENELITIAN}

Penelitian ini menggunakan metode kualitatif dengan analisis isi (content analysis). Penelitian kualitatif merupakan penelitian deskriptif yang menggambarkan data dengan kalimat yang dipisahkan menurut kategori untuk memperoleh simpulan (Arikunto 2009). Penelitian kualitatif adalah penelitian yang mengharuskan peneliti mengkaji fenomena yang terjadi secara alamiah dengan segala kompleksitasnya (Fraenkel dan Wallen, 2007).

Analisis isi adalah suatu teknik penelitian ilmiah yang ditujukan untuk mengetahui gambaran karakteristik isi dan menarik inferensi dari isi. Untuk mengidentifikasi secara sistematis isi komunikasi yang tampak dan dilakukan secara objektif, valid, reliabel dan dapat direplikasi (Eriyanto, 2011). Metode analisis isi juga dapat diartikan melukiskan variabel demi variabel (Rakhmat, 2005).

Data yang diambil dalam penelitian ini bersumber dari akun instagram capres dan cawapres yang dimulai dari masa pencalonan hingga masa kampanye. Beberapa sumber berita yang terkait capres dan cawapres juga menjadi data dalam penelitian ini. Teknik pengumpulan data adalah menggunakan studi dokumentasi. Dokumentasi terdiri atas isi pesan politik calon Presiden dan wakil Presiden di media sosial yang mendukung dokumen-dokumen dari instagram yang di screen shoot pada permasalahan yang akan diteliti.

\section{HASIL DAN PEMBAHASAN}

\section{Akun Media Sosial Instagram Jokowi-Amin}

Berdasarkan pengamatan yang telah dilihat dari akun tersebut total postingan akun @jokowi.amin pada bulan November 2018 hingga April 2019 berjumlah 145 postingan. Dalam postingan ini terdapat bermacammacam gambar serta video yang diunggah agar mempermudah masyarakat dalam membangun citra diri capres dan cawapres secara positif. Secara keseluruhan postingan dalam akun @jokowi.amin dapat dikelompokkan dalam tema ekonomi, politik, sosial dan kebudayaan.

Akun @jokowi.amin memiliki berita yang berhubungan dengan ekonomi berjumlah 21,38\% dari total 145 postingan. Postingan ini dapat 
dilihat pada tema "Wajah Indonesia 2009 dan 2019 \#10yearchallenge".

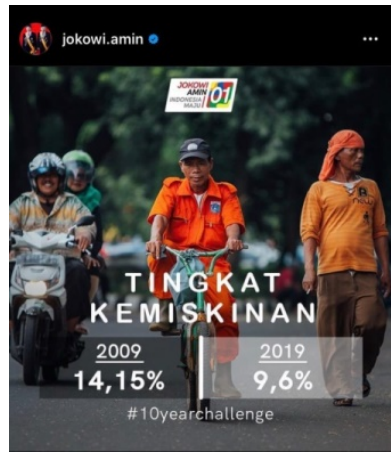

Dalam postingan ini terdapat 447 komentar serta 12.774 like oleh para netizen. Dalam kolom komentar terdapat pro kontra terhadap postingan ini. Salah satu akun yang menyatakan pro terhadap postingan ini @bambangagustriadi mengomentari bahwa "ini baru bukti nyata \& kerja hebat pak jokowi! lanjutkan pak kami siap mendukungmu". Sedangkan salah satu akun kontra postingan ini @ilhamzulfikaar mengomentari bahwa"HAHAHA Hoax".

Kemudian postingan yang bertemakan politik berjumlah 24, 14\% dari total 145 postingan. Postingan mengenai politik ini dapat dilihat pada foto yang bertuliskan "Kita layak menutup tahun 2018 dengan perasaan bangga dan salut, sebagai bangsa yang semakin berdaulat atas bumi dan kekayaan alam kita sendiri. Selama setengah abad, Blok Mahakam dikuasai oleh Total yang berasal dari Prancis dan Inpex Corporation dari Jepang. Sejak 1 Januari 2018, daerah kaya minyak dan gas di Kalimantan tersebut sudah dikelola sepenuhnya oleh Pertamina. Selama setengah abad juga, Blok Rokan di Riau dikelola oleh perusahaan Amerika, Chevron, dan pada 31 Juli 2018, blok ini kembali ke pangkuan Ibu Pertiwi.

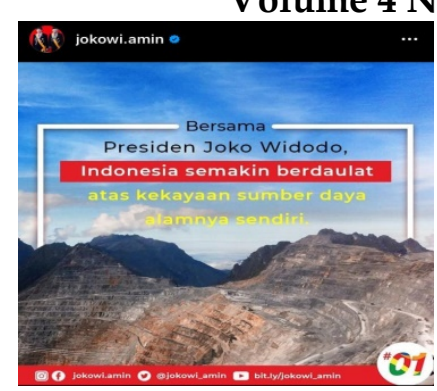

Pada 21 Desember 2018, pemerintah berhasil mengambil alih tambang Freeport di Papua. Jokowi dan timnya bernegosiasi selama 3,5 tahun, agar kita mendapatkan hak kepemilikan mayoritas Freeport Indonesia. Akhirnya, Freeport sudah milik Indonesia lagi. Sebelum ini semua terjadi, banyak yang skeptis dengan pemerintahan Jokowi bisa mengupayakan kedaulatan negara atas sumber daya alamnya. Pertambangan yang selama ini membutuhkan pengelolaan oleh pihak asing, kini sepenuhnya sanggup dikelola oleh tenaga dalam negeri.

Dalam postingan ini terdapat 25 komentar serta 1.152 like oleh para netizen. Salah satu akun pro terhadap postingan ini @toniwakwkw menyatakan: "lanjutkan pak jokowi 2 periode, rakyat masih cinta jokowi pemerintahannya, semangatlah, bangun trus indonesia raya ini bersama prop Kh makruf amin". Sedangkan alah satu akun yang kontra pada postingan ini @ citracicipas menyatakan: "wah soal FI ini pembohongan publik yang akan terungkap pada waktunya. Itu uang ngalirnya ke dana pilpres bukan untuk beli saham yang harus milik indonesia".

Sementara itu, postingan mengenai sosial berjumlah 43,45\% dari total 145 postingan. Di dalamnya bertuliskan "Pagi tadi, sebelum mengikuti rangkaian kegiatan di 
istana, Pak Jokowi datang menengok Ustaz Arifin Ilham yang sedang dirawat di Rumah Sakit Cipto Mangunkusumo, Jakarta Pusat. Walau singkat, keduanya berbincang dengan hangat. Pak Jokowi mengajak kita untuk mendoakan Ustaz Arifin, agar beliau cepat sembuh dan dapat kembali melanjutkan dakwah kepada masyarakat".

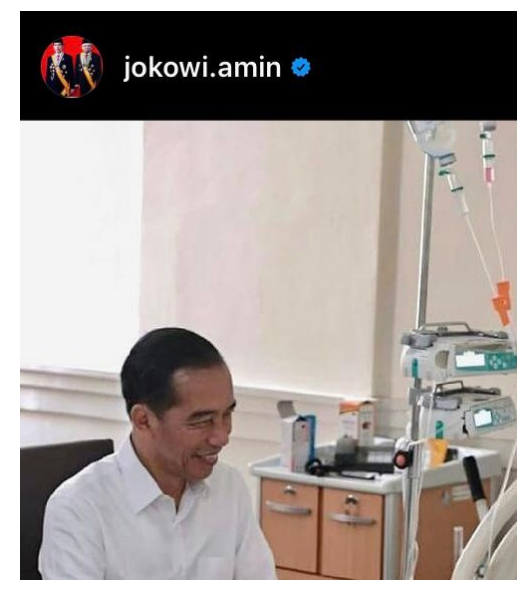

Pada postingan ini terdapat 106 komentar serta 2.316 like oleh para netizen. Salah satu akun pro terhadap postingan ini @rufianto93909 mengomentari bahwa "Pemimpin adalah imam...salut tuk pak jokowi...". Sedangkan salah satu akun yang kontra dengan postingan ini adalah @ilhamzulfikaar yang mengomentari: "Pencitraann banget...dekat pemilu...gak sabar nonton debat capres nanti..bisa gak ya jawabnya \#2019gantipresiden".

Postingan mengenai kebudayaan pada akun @jokowi.amin berjumlah $11,03 \%$ dari total 145 postingan. Postingan ini bertuliskan "Datu Seri Setia Amanah Negara, begitu gelar untuk Presiden Joko Widodo dari Lembaga Adat Melayu (LAM) Riau, yang disampaikan dalam sebuah prosesi meriah di Pekanbaru, pagi ini. Setidaknya, ada enam alasan di balik penganugerahan gelar itu. Ketua
Harian LAM Riau Datuk Seri Syahril Abubakar menyebutkan, gelar adat itu terkait berbagai peran Presiden Jokowi secara langsung terhadap masyarakat Riau.

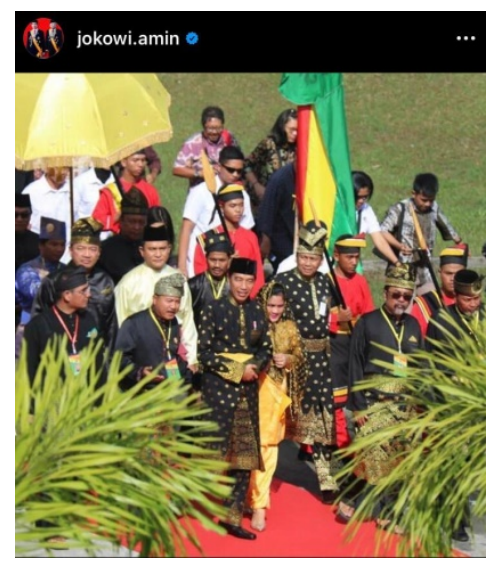

Pertama,

penanggulangan kebakaran hutan dan bencana asap yang kerap melanda daerah itu setiap tahunnya. Menurut Syahril Abubakar, sudah tiga tahun asap tidak datang lagi ke negeri ini (Provinsi Riau). Kedua, terkait reformasi agraria yang membuka peluang masyarakat adat Melayu memiliki pengakuan hukum atas tanahnya. Ketiga, peran Presiden dalam evaluasi dan peningkatan produktivitas perkebunan kelapa sawit yang menjadi mata pencaharian banyak masyarakat Riau.

Keempat, terkait dengan ladang minyak Blok Rokan yang hampir seabad dikelola oleh perusahaan asing, yang kemudian dinasionalisasi untuk dikelola oleh Pertamina. Kelima, masyarakat adat Riau mengapresiasi pembangunan infrastruktur, seperti jalan tol di Riau. Keenam, rencana mewujudkan embarkasi untuk calon jemaah haji di Kota Pekanbaru.

Dalam postingan ini terdapat 7 komentar serta 713 like oleh para netizen. Salah satu akun pro terhadap postingan ini @jentrit mengomentari: "sehat selalu pak de jokowi". Sedangkan salah satu akun kontra postingan ini, @adnugg 
Volume 4 No. 22021

mengomentari: "waduh yang point ke empat agak berlebihan yaa".

Dari penjabaran data tersebut capres dan cawapres Jokowi-Amin memberikan pesan politik di bidang: ekonomi, politik, sosial serta kebudayaan. Masing-masing postingan telah menarik perhatian masyarakat Indonesia dengan berbagai komentar, baik dalam bentuk positif maupun negatif.

\section{Akun Media Sosial Instagram Indonesia Adil Makmur}

Total postingan akun @Indonesiaadilmakmur yang menjadi akun resmi dari pasangan PrabowoSandi Uno berjumlah 96 postingan. Jumlah ini terhitung dari bulan November 2018 - April 2019 dalam jangka waktu penelitian. Peneliti mengamati pesan politik yang dapat dikelompokkan dalam tema: ekonomi, politik, sosial dan budaya.

Akun@Indonesiaadilmakmur memiliki postingan dengan tema ekonomi berjumlah 26,04\% dari total 96 postingan. Salah satu postingan mengenai ekonomi ini dapat dilihat pada tulisan "Memastikan harga yang terjangkau merupakan komitmen \#neweraprabowosandi".

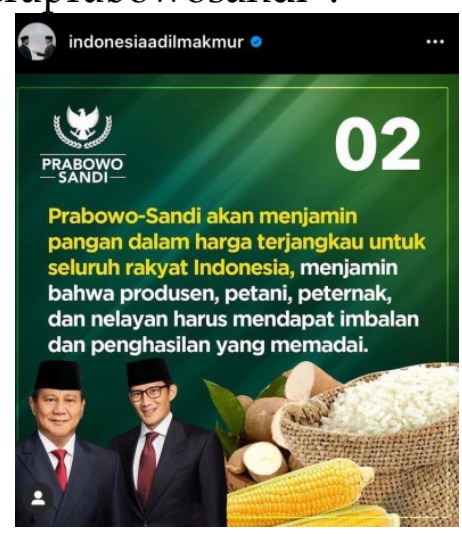

Dalam postingan ini terdapat 127 komentar serta 9.200 like oleh para netizen. Salah satu akun yang pro terhadap postingan ini adalah @tirtadolly. Dia mengomentari bahwa "demi Indonesia adil dan makmur...gemah ripah loh jinawi...Prabowo sandi is my choice...Aamiin yaa Mujib". Sedangkan salah satu akun kontra berasal dari akun @baharisahrull yang mengomentari: "maksudnya yang online-online gitu". Hal ini terlihat seperti mengolok pasangan capres dan cawapres.

Akun@Indonesiaadilmakmur memiliki tema politik yang berjumlah $43,75 \%$ dari total 96 postingan. Postingan ini dapat dilihat pada tulisan "Semua rencana reklamasi yang tidak sesuai dengan tata aturan, merusak kualitas ekosistem \& lingkungan hidup, merusak kehidupan ekonomi sosial dan masyarakat akan dihentikan \#prabowosandimenang".

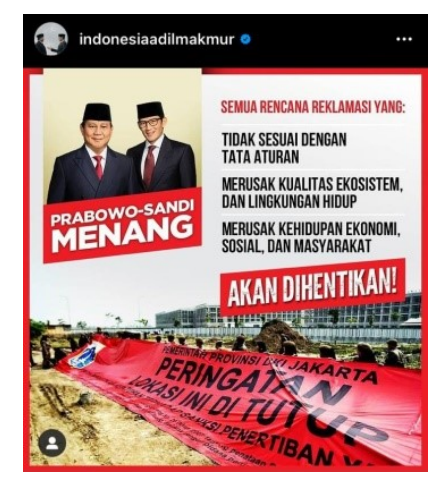

Dalam postingan ini terdapat 170 komentar serta 9.831 like oleh para netizen. Salah satu akun yang pro terhadap postingan ini adalah @ detective_imut. Dia berkomentar "Alhamdulillah, bener2 mewakili suara hati rakyat, Alhamdulillah semoga negeri ini menyusul mendapat berkah kebaikan seorang pemimpin". Sedangkan salah satu akun yang kontra terhadap postingan ini @rioabrianto07 mengomentari 
“buat perjanjian di materai aja... kalau gag dihentikan gmna?".

Sementara itu, tema ekonomi dan sosial dalam akun @Indonesiaadilmakmur berjumlah $23,96 \%$ dari total 96 postingan. Postingan mengenai ekonomi sosial ini dapat dilihat pada postingan yang bertuliskan "Dalam keadaan apapun, penguatan ekonomi harus menjadi prioritas. Keluarga korban harus kembali mendapatkan penghasilan dan memperoleh pekerjaan agar dapat memenuhi hajat hidupnya. Bila ekonomi terjaga maka Insya Allah pendidikan dan kesehatan mereka juga terjaga dan ekonomi Sulawesi Tengah bisa terbangun kembali".

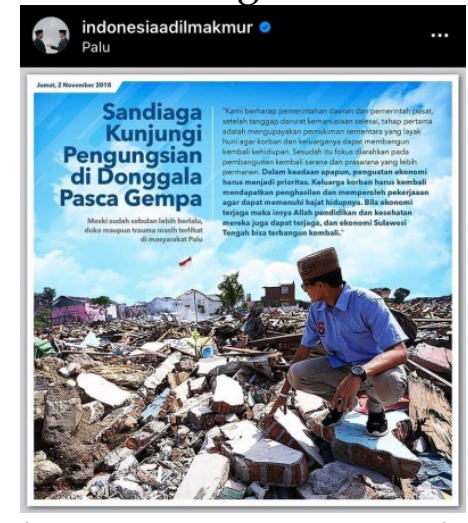

Pada postingan ini terdapat 20 komentar serta 2.289 like oleh para netizen. Salah satu akun yang pro terhadap postingan ini adalah @masnah234. Dia berkomentar: "sekarang dunia sudah tua, musim gempa, sunami tidak hanya dilaut saja, sunami darat pun ada, mari sama-sama kita merenung, sudahkah kita berbuat baik didunia ini, sudahkah kita berguna untuk orang2 banyak. Harta itu penting, tapi bukan segala-galanya. Belum tentu harta banyak itu menuju bahagia yang abadi".

Tema kebudayaan dalam akun @Indonesiaadilmakmur berjumlah $6,25 \%$ dari 96 postingan. Tema ini dapat dilihat pada postingan yang bertuliskan "Koalisi Indonesia Adil Makmur mengucapkan selamat memperingati Maulid Nabi Muhammad SAW...."

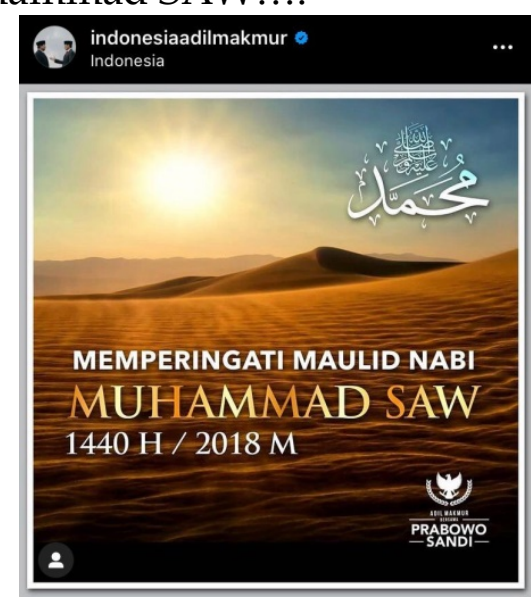

Dalam postingan ini terdapat 21 komentar serta 3026 like oleh para netizen. Salah satu akun yang pro terhadap postingan ini adalah @poniemslamet. Dia berkomentar dengan mengatakan "semoga kita selalu mendapat syafaatnya. Aamiin YRA. Bp H. Prabowo Subianto Presiden kita thn 2019".

Berdasarkan data keseluruhan dari dua akun ini, peneliti melihat bahwa Jokowi-Amin dalam menyampaikan pesan politiknya lebih menekankan kepada aspek sosial. Hal ini dikarenakan terdapat 43,45\% postingan yang bertemakan sosial. Sementara itu, pasangan PrabowoSandi lebih menekankan kepada aspek politik. Hal ini terlihat dari $67,41 \%$ postingan pasangan ini bertemakan politik.

\section{KESIMPULAN}

Komunikasi politik merupakan proses penyampaian pendapat, sikap dan tingkah laku orang, lembaga, atau kekuatan politik, dalam rangka mempengaruhi pengambilan keputusan politik. Semua kegiatan politis yang dilakukan oleh pemerintah atau kekuasaan negara 
beserta institusi pendukung maupun yang dilakukan rakyat pada umumnya merupakan bentuk komunikasi politik (Susanto, 2013).

Dalam komunikasi politik yang dilakukan oleh pasangan capres dan cawapres dalam pemilu tahun 2019, terdapat beberapa tema yang menyangkut aspek: sosial, ekonomi, politik dan budaya. Kedua pasangan capres dan cawapres merespon masalah-masalah terkini yang terkait dengan tema tersebut dan direspon secara pro dan kontra oleh netizen.

\section{DAFTAR PUSTAKA}

Arikunto, S., 2009. Prosedur Penelitian Suatu Pendekatan Praktik. Edisi Revisi 6. Jakarta : Rineka Cipta

Baron, R. A dan Donn Byrne. 2003. Psikologi Sosial. Jakarta: Erlangga.

Damayanti, Alfi Sari Nastiti, Dian Purworini. 2018. Pembentukan Harga Diri: Analisis Presentasi Diri Pelajar SMA di Media Sosial. Jurnal Komunikasi ISSN 2085-1979, EISSN 25282727 Vol. 10, No. 1, Juli 2018

Susanto, Eko Harry, (2013). Dinamika Komunikasi Politik Dalam Pemilihan Umum. Jurnal Kajian Komunikasi, Volume 1, No. 2, Desember 2013.

Eriyanto. 2011. Analisis Isi: Pengantar Metodologi untuk Penelitian Ilmu Komunikasi dan Ilmu-ilmu Sosial Lainnya. Jakarta: Kencana.
Fraenkel, J. R. \& Wallen, N. E. (2007). How to Design and Evaluate Research in Education. Singapore: The McGraw-Hill Companies

Miriam Budiardjo. 2008. Dasar-Dasar Ilmu Politik. Jakarta: Gramedia Pustaka

Mulyana, Deddy (2010). Ilmu Komunikasi Suatu Pengantar, Cet. XIV. Bandung: PT. Remaja Rosdakarya.

Nasrullah, Rulli. (2015). Media Sosial Perspektif Komunikasi, Budaya Dan Sosioteknologi. Bandung: Simbiosa Rekatama Media

Pawito. 2009. Komunikasi Politik Media Massa dan Kampanye Pemilihan. Yogyakarta: Jalasutra.

Rakhmat, Jalaluddin, 2005. Psikologi Komunikasi. Bandung: Remaja Rosdakarya

Solis, B., Breakendridge D. (2009). Putting the Public Back in Public Relations: How Social Media Is Reinventing The Aging Business of PR. New Jersey: Pearson Education Inc.

Watie, E. D. S. (2016). Komunikasi dan media sosial (communications and social media). Jurnal The Messenger, 3(2), 69-74 